\title{
Building Civilization with Literacy: Reactualization of the Ulil albâb Concept in Muslim Religion in Indonesia
}

\author{
$1^{\text {st }}$ Faris Maulana Akbar ${ }^{1}, 2^{\text {nd }}$ Iik Arifin Mansurnoor ${ }^{1}, 3^{\text {rd }}$ Didin Saepudin $^{1}$ \\ \{afsirmlajah11@gmail.com¹, iik.arifin@uinjkt.ac.id ${ }^{1}$,didin.saepudin@uinjkt.ac.id ${ }^{1}$ \} \\ UIN Syarif Hidayatullah, Islamic Studies Department, Jakarta, Indonesia ${ }^{1}$
}

\begin{abstract}
This study discusses the concept of ulil albâb which was once popular in Indonesia as "Muslim scholar". This study is important. It relates to the low condition of Indonesian literacy. In fact, Indonesia's majority is Muslim. By using descriptive-analytic methods this study tries to evaluate the Muslims religion today. This study aims to find solutions to improve Muslim literacy to achieve advanced civilization. This study found dichotomy of religious practices and the imbalance in the practice of knowledge as two main problems. Those are two factors that make Muslim literacy low. The concept of ulil $a l b a \hat{b} b$ which combines the power of dhikr, thought and deed needs to be re-actualized to overcome the problem.
\end{abstract}

Keywords: the concept of ulil albâb, islamic civilization, literacy, muslim society.

\section{Introduction}

Muslim scientific passion at this time should be appreciated. The lively spread of Islamic knowledge is becoming a trend among Indonesian Muslim youth. Islamic studies are everywhere. However, this enthusiasm is not comparable to the condition of the people who are still slumped in the world of general science.

Judging from several events in recent years, Muslims in Indonesia are more concerned with normative matters, precisely those related to Shari'a. Very few of them really want to explore general scientific knowledge. This is evident from the survey which states that Indonesian literacy is very low [1] In fact, based on philosophical studies, the concepts of Islam, science, and culture are actually connected. In an article, Asyhari expanded the definition of "scientific literacy" developed by the OECD (2016) which initially "as a reflection as citizens" became "as a reflection as citizens of a religious and cultured state". [2] He also said the definition of scientific literacy according to PISA is "the ability to engage with science-related issues, and with the ideas of science, as a reflective citizen" [2]

According to the OECD, someone who has a scientific literation needs several competencies, those are explain the phenomenon scientifically, evaluate and design scientific investigations, and interpret data and evidence scientifically. [1] In addition, there are 4 aspects that form the framework of scientific literacy, namely: contexts, knowledge, competencies, and attitudes [2]. Scientific literacy and Islamic literacy have become as guarantors of the quality of Indonesian people in the modern era. Based on the PIRLS study, it is known that students in Indonesia can only read explicitly without being able to think further (critically, analytically) from their reading [3]. Khamami et.al [4] in their paper mention about the effect of digital literacy to tendency on extremism. 
The condition of the community above is quite alarming. Because, in the 1980-90s, Indonesian Muslims aspired to build an advanced civilization. The discourse of "ulil albâb" (which was more popular with "cendekiawan muslim"/"Muslim scholars") was disseminated for the achievement of these noble ideals. To make this discourse a success, they formed Ikatan Cendekiawan Muslim se-Indonesia (ICMI)/ the Indonesian Muslim Intellectual Association as a vehicle for aspiration and movement. One of ICMI's missions is to advance Indonesian Islamic civilization within 20 years.

Responding to the condition explained above, the researchers tried to trace the concepts promoted by ICMI, namely Muslim scholars. This concept they took from the concept of ulil $a l b a \hat{b} b$ in the Qur'an. According to the author, this concept needs to be reviewed in order to be revitalized to increase Indonesian literacy.

\section{Terms}

The concept of ulil albâb here is a concept taken from 16 verses about ulil albâb in the Koran. This concept is understood with the help of interpretations of classical to contemporary scholars.

Civilization referred to here are all things that include culture that has a technological system, building art, fine arts, state system and advanced and complex science. [5] This is in accordance with the meaning of civilization in Oxford "a society which has its own highly developed culture and way of life" or "an advanced state of social and cultural development, or the processes of reaching this state". Civilize itself means "to make people or a society develop from a low social and cultural level to a more advanced one." [6]

Meanwhile, the literacy meant here is understanding according to Oxford "the ability to read and write" from literate which means "able to read and write". [6] [7]

Based on the terms mentioned, this research will focus on the concept of ulil albâb to advance Indonesian civilization with literacy.

\section{Methods}

This qualitative research focuses on the contextualization of the concept of ulil albâb in the Koran. Primary data is 16 verses in the Koran. Whereas secondary data is the interpretation of the ulama, especially Indonesian ulama. Then, using descriptive-analytic methods, the researcher tries to contextualize the concept in the main problem. The approach used is the anthropological and sociological approach, so that it can find solutions to existing problems. [8]

The researcher divided three stages in this study, namely ontology, epistemology, and axiology. [9] Ontology will discuss the identity of ulil albâb. Epistemology examines the root of the research problem and how the ulil albâb concept works in solving the problem. Axiology analyzes the application of the concept of ulil albâb. 


\section{Findings}

\subsection{Ulil albâb in al-Qur'an}

The term ulil albâb is mentioned 16 times in the Qur'an. Nine of them are found in the Makkîyyah verse and the remaining seven are Madanîyyah. The details are: Q.S.al-Baqarah [2]: 179, 197 and 269; Q.S. Âli 'Imran [3]: 7 and 190; Q.S. al-Maidah [5]: 100; Q.S. Joseph [12]: 111; Q.S. al-Ra'd [13]: 19; Q.S. Ibrâhîm [14]: 52; Q.S. Sâd [38]: 29 and 43; Q.S. al-Zumar [39]: 9, 18 and 21; Q.S. Ghafir [40]: 54, Q.S. al-Talâq [65]: 10.

Each of the above verses has their respective contexts. The context of some verses are similar, but the majority is different. Through this context, we can identify the special characteristics of ulil albâb as follows:

Table 1. Characteristics of Ulil albâb according to Qur'anic Context

\begin{tabular}{|c|c|}
\hline Verse & Characteristics (Qur'anic Context) \\
\hline Q.S.al-Baqarah [2]: 179 & who are pious and able to understand the wisdom behind shari'ah (qisâs) \\
\hline Q.S.al-Baqarah [2]: 197 & $\begin{array}{l}\text { who fear and stay away from the prohibition of Allah (prohibitions during } \\
\text { the pilgrimage) }\end{array}$ \\
\hline Q.S.al-Baqarah [2]: 269 & who were given wisdom and were able to take lessons from him \\
\hline Q.S. Âli ‘Imrân [3]: 7 & $\begin{array}{l}\text { who have knowledge, have faith, and are able to take lessons from } \\
\text { muhkam and mutasyâbih verses and expect the grace of Allah }\end{array}$ \\
\hline $\begin{array}{l}\text { Q.S. Âli ‘Imrân [3]: } \\
\text { 190-195 }\end{array}$ & $\begin{array}{l}\text { who always remembers (remembers Allah) and thinks about the creation } \\
\text { of nature, aware of the benefits of all God's creations, fear of the } \\
\text { punishment of hell, aware of the power of God, have faith, always repent, } \\
\text { and expect God's grace }\end{array}$ \\
\hline 100 & and bad and $\mathrm{al}$ \\
\hline Q.S. Yusuf [12]: 111 & $\begin{array}{l}\text { revious people (the apostles before the } \\
\text { ble to take lessons from him }\end{array}$ \\
\hline Q.S. al-Ra & $\begin{array}{l}\text { who can learn from the difference between people who know the truth and } \\
\text { who are blind, keep promises and not break them, obey by Allah's } \\
\text { commands, fear of bad reckoning, be patient because they expect the } \\
\text { pleasure of Allah, establish prayers and invest some of the good fortune } \\
\text { blessed by God both hidden or open, and reject evil with good }\end{array}$ \\
\hline Q.S. Ibrâhîm & who \\
\hline Q.S. S & who \\
\hline Q.S. $\underline{\text { Sâd }[?]}$ & s of the previous \\
\hline Q.S. al-Zumar [39]: 9 & the difference be \\
\hline Q.S. al-Zun & who \\
\hline Q.S & $\begin{array}{l}\text { who is able to take lessons from natural phenomena (rain and plant life } \\
\text { processes) }\end{array}$ \\
\hline 54 & who receive guidance and $\mathrm{w}$ \\
\hline Q. & $\begin{array}{l}\text { who fear, believe, and get a warning (the apostle who rea } \\
\text { Allah) }\end{array}$ \\
\hline
\end{tabular}

When examined closely, it can be concluded that ulil albâb is a Muslim who has faith, is pious, obedient and diligent in worship, always dhikr to Allah, knowledgeable and knowledgeable, and is able to take lessons from the phenomena around him both natural phenomena and natural phenomena. as well as social behaviors. [10] 
It should be noted, "taking lessons" referred to here is the interpretation of lafadz "yatadzakkaru" or "yadzdzakkaru" which often appears when lafadz "ulil albâb" is mentioned in the verse. Both lafadz are from the same root word as dhikr, namely: dzakara. Dhikr later became the main character ulil albâb.

The identification of the characteristics of ulil albâb is the result of direct observation of the author based on the verses of ulil albâb in the Qur'an. Since there are a number of verses which are connected to the previous paragraph, or are still related to the following paragraph, the author also incorporates several characteristics of the continuation of the verse. The results of reading the characteristics of ulil albâb are not too much different from the results of other researchers' readings, as like Sri. [11]

Judging from the conclusion, it seems that Sri only quoted and slightly added the opinion of Jalaluddin Rahmat who mentioned the five characteristics of ulil albâb. The five characteristics are: first, earnestly seeking knowledge (Q.S. Âli 'Imrân [3]: 7 \& 190); second, being able to separate the bad from the good, then he chose the good, even though he had to oppose the people (QS. al-Mâidah [5]: 100); third, critical in listening to the conversation, good at weighing words, theories, and arguments put forward by others (Q.S. al-Zumar [39]: 18); fourth, conveying their knowledge to improve their communities, giving warnings, and defending them when injustice occurs (QS. Ibrâhîm [14]: 52. Q.S. al-Ra'd [13]: 19-22); Fifth, do not fear anyone except Allah (Q.S. al-Baqarah [2]: 197, Q.S. al-Mâidah [5] 179, Q.S. alTalâq [65]: 10).

In addition to the general characteristics above, Jalaluddin Rahmat gives special characteristics of ulil albâb which are only owned by ulil albâb and that makes him different from scientists or intellectuals, namely: diligent worship, wake up at night to bow and bow 'before God and ask forgiveness Him (QSal-Zumar [39]; 9). Another distinctive sign is always remembering him all the time (QS. Âli 'Imrân [3]: 191). Because of this special sign, Jalaluddin Rahmat concluded that ulil albâb was a pious scientist or intellectual. [12]

\subsection{The Concept of Ulil albâb in al-Qur'an}

As mentioned earlier, the main character of ulil albâb is dhikr. The concept of Dhikr ulil albâb includes dhikr and thinking. Regardless of whether they think first then dhikr, or dhikr first then think. The concept of ulil albâb requires that a Muslim always learns, reads the situation.

Etymologically, ulil albâb is a combination of two words from ulû (have) and albâb (reason). [13] A combination of these two words is often interpreted as 'having reason'. Albâb is the form of the clock 'al-taktsîr from lubb (لب) which can mean' essence of something ',' reason ', and' poison '. as long as 'permanence and permanence and purity and kindness'. [14] However, in the meaning of ulil albâb, the meaning of the first $l u b b$ (essence) is used. For example, in Tafsir al-Mishbah Quraish Shibab gives an example of beans. Beans have a skin that covers the contents. The contents of these beans are called lubb. [15] The interpretation of $l u b b$ as the essence of something indicates that ulil albâb is people who have the ability to know the essence of something.

Besides meaningful 'essence', actually $l u b b$ can mean 'brain', 'mind', 'intellect'. [14] Ulil $a l b a \hat{b}$ means someone who has more thought than anyone else, both because of his intelligence and intensity. Therefore, ulil albâb can be a thinker, scholar, scholar, or philosopher who thinks deeply. [16]

$L u b b$ also means 'intellect'. Someone is called labîb because he is intelligent. [14] However, the meaning of 'reason' on the lubb is not the same as the meaning of 'reason' lafadz 
'aql. The difference between $a l-l u b b$ and $a l$ - $a q l$ is that $a l-l u b b$ means something that is pure from the properties of the properties it attributes while $a l$ - $a q l$ means something that includes what is already known from something that it attributes. [17] $L u b b$ is a pure intellect from defects or intelligent intellect. [18] Therefore, every lubb is intellect but not all intellect is $l u b b$. [19]

Among the mufassir who interpret lubb with al-'aql are al-Tabarî [20], al-Qurtubî [21], Ibn Katsîr [22] and Ibn 'Asyur [23]. Ibn Katsir explained that albâb is an intelligent perfect mind that knows something based on actual reality (haqâiqihâ). Therefore, ulul albâb is not like the blind and deaf people that Allah described in His words, "And how many signs (the greatness of Allah) in the heavens and the earth they pass through, but they turn away from them. And most of them do not believe in Allah, even they associate partners with him. [22]

Before Ibn Kathir, al-Qurtubî had said something not much different. In the interpretation of Q.S. Âli 'Imrân (3): 190, he explained, "Ulil albâb are those who use their minds when contemplating the signs given by Allah." [21] This means ulil albâb are those who think because reason is a tool for thinking.

M. Quraish Shihab in his interpretation explained that ulil albâb are people who have pure reason, which are not covered by 'skin', namely the fog of ideas, which can give rise to confusion in thinking. With this mind they understand God's instructions, meditate on His decrees, and carry them out. They are no longer shackled by animalistic lusts or controlled by the invitation of the elements of the soil dust. They are anyone who constantly remembers Allah with words and or hearts, and in all situations and conditions. [15] Therefore, according to the scholarsphysicist Bahaudin Mudhary, ulil albâb are believers who are always accompanied by angels who always pray for them. They get angelic intuition or intellectual intuition. [24]

In Indonesia, ulil albâb tends to be interpreted by scholars. In terms of etymology, both have the same meaning. In the Big Indonesian Dictionary, the word "intellectual" is interpreted as "a person who constantly improves his thinking ability to be able to know or understand something". The word comes from the word "Scholar" which among others means "quickly understand the situation and is good at finding a way out." [25] Whereas in the Popular Scientific Dictionary, "Scholar" means "wise, wise, intelligent, high in intelligence" and " intellectual "means" a scholar; intelligence; intellectual ". [26]

As for the equivalent of the word in the Indonesian Alphabetical Dictionary Thesaurus Language Center, "Scholar" can mean "pithy, brilliant, brilliant, intelligent, clever, dilute, genial, genius, intellect, intelligence, concipent, clever, clever, smart, light head, sharp, bright reason "which is the antonym of" fool ". While the word "intellectual" is commensurate with "clever scholar, clever scholar, scientist, intellectual, Jauhari, scholar, writer." [27] Based on these various meanings, intellectuals are identified as people who excel in their thinking power just like the understanding of ulil albâb who the author has explained before.

However, despite having the same meaning, the Qur'an has referred to some special characteristics as the characteristics of ulil albâb. This indicates that the meaning of "intellectual" alone does not adequately represent the essence of ulil albâb. Therefore, it is very important to know these characteristics as stated in the Book of Allah. Therefore, the authors tend to use the concept of ulil albâb rather than scholars.

\subsection{The Concept of Tadzakkur}

Ulil albâb is known as a figure of thought and dhikr [29]. This is inseparable from the explanation of the Qur'an concerning himself. The verse that clearly states these characteristics 
is Q.S. Âli 'Imran (3): 190-191. In addition, there are 10 out of 16 verses in the Qur'an that mention ulil albâb and attribute them to the equivalent of lafadz dhikr. That is, as a whole there are eleven verses that mention ulil albâb and zikr together. The eleven verses are: Q.S. alBaqarah [2]: 269, Q.S. Âli 'Imran (3): 7 \& 191, Q.S. al-Ra'd (13): 19, Q.S. Ibrâhîm [14]: 52, Q.S. Sâd [38]: 29 \& 43, Q.S. al-Zumar [39]: 9 \& 21, Q.S. Ghafir (40): 53-54, and Q.S. al-Talâq (65): 10.

Based on these verses, it is known that the equivalent of the word dhikr used in the description of the figure of ulil albâb in the Qur'an is lafadz: yadzkurûna, yadzdzakkaru, yatadzakkaru, dzikr, and dhikrâ. Each verse that contains the equivalent of that word has a different object / context. These differences the authors show in the following table:

Table 2. The Derivation of $d z i k r$ in ulil albâb's verses

\begin{tabular}{|c|c|c|}
\hline Term & Verse & Object/ Context \\
\hline Yadzkurûna & Q.S. Âli 'Imrân [3]: 191 & Allah \\
\hline \multirow{3}{*}{ Yadzdzakkaru } & Q.S. al-Baqarah [2]: 269 & $\underline{\text { Hikmah }}$ \\
\hline & Q.S. Âli 'Imrân [3]: 7 & Muhkam \& Mutasyâbih \\
\hline & Q.S. Ibrâhîm [14]: 52 & Al-Qur'an \\
\hline \multirow{3}{*}{ Yatadzakkaru } & Q.S. al-Ra'd [13]: 19 & $\begin{array}{l}\text { The truth of the Qur'an, the } \\
\text { comparison between people } \\
\text { who know and are blind }\end{array}$ \\
\hline & Q.S. S $\underline{\text { âd [38]: } 29}$ & Kitab (al-Qur'an) \\
\hline & Q.S. al-Zumar [39]: 9 & $\begin{array}{l}\text { the comparison between people } \\
\text { who know and are blind }\end{array}$ \\
\hline Dzikr & Q.S. al-Talâq (65): 10 & Rasul \\
\hline \multirow{3}{*}{ Dzikrâ } & Q.S. S Sâd [38]: 43 & $\begin{array}{l}\text { The Story of the Prophet Ayyb } \\
\text { As }\end{array}$ \\
\hline & Q.S. al-Zumar [39]: 21 & Rain event \\
\hline & Q.S. Ghâfir [40]: 53-54 & Al-Kitâb (Torah) \\
\hline
\end{tabular}

Judging from the table above, among the several lafadz dhikr and their forms of derivation, only Q.S. Âli 'Imrân [3]: 191 (yadzkurûna) whose object is Allah. Other verses refer to various objects and not to God. That is, in zahir, there is only one verse whose meaning of zikr is oriented to the term of zikr which is used by Sufism. While the meaning of zikr in other verses is related to the lesson or warning of the object he mentioned. If the two forms of zikr are both done by ulil albâb, the question that should be raised here is: are the two kinds of zikr a same or different work? To answer this question, in the following sub-chapter the author describes the commentators' interpretation of it.

Based on a little interpretation of the scholars of the lafadz-lafadz derivation of zikr in the verses of ulil albâb, the author sees that there is a common thread related to the use of lafadz dhikr and its derivation in describing the reasoning activities carried out by ulil albâb. The red string is the author feels after looking at the use of four derivations of lafadz dhikr, namely yadzkuru, yatadzakkaru / yadzdzakkaru, dzikr, and dzikrâ. If each use of lafadz is mapped into a single integrated unit with information on the type of lafadz and the object of its discussion, then the picture will be like the following table: 
Table 2. The Derivation of $d z i k r$ in ulil albâb's verses

\begin{tabular}{|c|c|c|l|}
\hline Lafadz & Type & Object & \multicolumn{1}{c|}{ Function } \\
\hline Yadzkuru & Fi'il (verb) & Allah & $\begin{array}{l}\text { A transcendental } \\
\text { thinking activity } \\
\text { carried out by } \text { ulil } \\
\text { albâb }\end{array}$ \\
\hline $\begin{array}{l}\text { Yatadzakkaru/ } \\
\text { yadzdzakkaru }\end{array}$ & Fi'il & $\begin{array}{l}\text { Scripture } \\
\text { Creature }\end{array}$ & $\begin{array}{l}\text { Describing the } \\
\text { process of thinking } \\
\text { ulil albâb whose } \\
\text { object is other than } \\
\text { Allah }\end{array}$ \\
\hline Dzikr/dzikrâ & Ism (noun) & $\begin{array}{l}\text { The mind object of } \\
\text { ulil albâb will deliver } \\
\text { it to the } \\
\text { transcendental } \\
\text { thought process }\end{array}$ \\
\hline
\end{tabular}

For more details, let's look at the following picture:

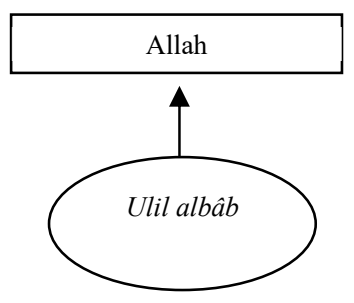

Fig. 1. Ulil albâb remembers Allah (yadzkurûna-llâh)

In this picture it appears that the activities of the intellect point upward, in the transcendental direction. Here, ulil albâb only remembers without thinking about it. This is in accordance with the command of Allah Almighty that humans think of His creatures and not think of Him.

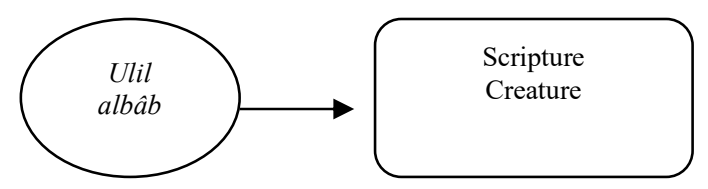

Fig. 2. Ulil albâb takes warnings / lessons (yatadzakkaru / yadzdzakkaru)

In this picture the direction of ulil albâb seems sideways. Here, they begin to activate their mind. They began to observe objects in the form of scriptures and creatures to learn and take advantage of. In addition, they also make these objects as zikr. Therefore, in fact this illustration is also suitable for describing yatafakkarûna thinking activities in Q.S. Âli 'Imran (3): 191. 


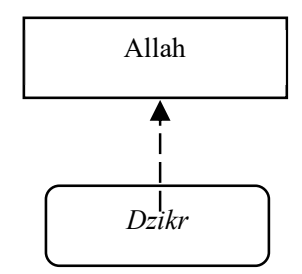

Fig. 3. Dhikr / Dhikrâ as objects of thought which lead to transcendence

This picture explains that dhikr as the object of tadzakkur ulil albâb turned out to make his observers (ulil albâb) remember Allah. Therefore, indirectly all the dhikr that become the object of the tadzakkur are directed upward, in the transcendental direction as the yadzkurûna-llâh process in point.

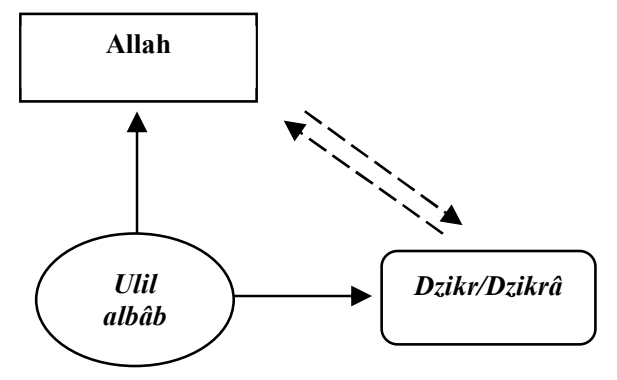

Fig. 4. The Ulil albâb's thought process

Through this picture, the author wants to convey that there is a circulation of thought that occurs in ulil albâb's mind where the ultimate goal is God. If the mind moves towards the top, then it is only limited to "remembering" which is commonly called the term dhikrullah. Whereas if the activity of the mind moves sideways toward the creatures of God, then at that time he thought deeply so that he learned that what he thought was related to the Above. This is what is called tadzakkur, namely the process of thinking with active reason until it reaches something that is Right. The dotted arrowhead from Allah to Zikr / Dhikrâ is an illustration of Allah's commandment so that people think of His creatures. Based on this combined scheme, it can be seen that both yadzkurûna, yatadzakkaru / yadzdzakkaru, or dzikr / dzikrâ ultimately show the meaning of dhikrullâh, that is to remember Allah.

\section{Discussion}

There are several questions that should be presented in this last sub-chapter. These questions are expected to be able to reflect the essence of the study in this study from beginning to end. From all the questions, the writer formulated two big questions that represented the other questions.

First, judging the interpretation of ulama on the term ulil albâb, actually the concept of ulil albâb (including the concept of dhikr) did not experience development, even impressed 
stagnant. After entering the modern age, a number of commentators began to develop the concept. Dawam Rahardjo, as a Muslim thinker who lives in modern times is one of those who developed the concept by contextualizing it in the Indonesian context. The question is, why does this phenomenon occur?

Second, based on a discussion of the concept of Muslim scholars who combine the quality of dhikr and thought, the authors see there is a persuasive movement for scholars to enter the world of intellectuals / intellectuals by developing science while intellectuals / intellectuals enter the world of scholars by increasing religious quality. The question is, why does this phenomenon occur?

In answer to the first question, the author wants to invite the reader to re-discuss the writer's discussion in Findings section and relate it to the historical context.

The concept of ulil albâb is displayed from the time of the Prophet Muhammad to the modern age. The stagnant interpretation is found in classical interpretations. The interpretation seems to be still normative and is always repeated by the commentators even though it has been in a different era. The contents are only in the form of an explanation in understanding and taking wisdom of ulil albâb verses without mentioning the concrete question of their existence and real role. This is understandable, because in those days, science was not as advanced as science in the modern age developed by the West. Therefore, ulil albâb, known as a scholar, is actually more visible in the figure of ulama or pious people who have above average intelligence and have nothing to do with the rapidly developing new science after the Renaissance.

Meanwhile, in the modern interpretation, the exegete's understanding of the concept of ulil $a l b a \hat{b}$ is inseparable from their perception of the development of modern science in which technology is a spectacular product. It is well known that modern science emerged because the West discovered the quality of reason. The adage "Cogito ergo sum!" Coined by Rene Descartes, a famous philosopher from France is proof that the West has realized the greatest potential of humanity. In this era of great scientists were born who with his knowledge then brought drastic changes to the world. In this context modern commentators live so that their projection of ulil albâb as a rational person leads to the figure of a scientist who emerged in the West.

M. Dawam Rahardjo, as a Muslim living in Indonesia, was able to read the conditions of the era at that time. He realized that a Muslim should be able to keep up with the times, not even antipathy or even reject it. In his view, a Muslim must come forward. On the one hand, he regretted the reality of Muslims in Indonesia, especially among the ulamas who were still shackled in their classical world and did not look towards the progress of the times. On the other hand, he also regretted intellectuals or intellectuals who were able to keep up with the flow of the times were apparently unable to assimilate themselves into society. In fact, Dawam sees that the majority of Indonesian Muslims are "under the control" of the ulemas, not the scholars. Therefore, when the term ulil albâb has been discovered in the Koran, he helped develop the concept of ulil albâb by contextualizing it in the times and also in the Indonesian context in the discourse of "Muslim scholars" which is a combination of scholars and scholars with the hope that both scholars and scholars are able to bring people to answer the challenges of the times.

In connection with the description above as well as answering the second question, the author would like to invite the reader to enter into a strategy carried by Indonesian Muslim thinkers - including Dawam - in their efforts to integrate the functions of scholars and scholars in the community. Ulama are community leaders whose behavior is emulated by the community. In the field of religion, they are not only model figures, but also as leaders who are responsible for the benefit of their people. In the modern era, the problems of the Ummah are not merely 
related to Jurisprudence. Along with the times, their problems are increasingly complex with the entry of technology and various sciences.

Therefore, as a leader, a scholar also knows a lot of the problems being faced by the people. Like it or not, scholars must improve the quality of his thought and add scientific insights. Moreover, in modern times religion - especially al-Qur'an as a holy book and a way of life for Muslims - is beginning to be understood and interpreted by the findings of modern science that are very different from the explanations described by classical scholars. This is where the cleric is held accountable in addressing various modern phenomena in order to be able to guide modern people on the path that should be taken.

Meanwhile, Muslim scholars as scientists who master modern science also have the same responsibilities as scholars in terms of helping the welfare of the people with their knowledge and reasoning power. Since the majority of Indonesia's population is religious Muslims, a Muslim scholar should understand their characteristics, especially in terms of culture. Here, they will realize that Muslim societies are more obedient to scholars because in their view, scholars are closer to God. In reality, Muslims do believe more in clerics than scholars. Therefore, a Muslim scholar should improve the quality of his religion both in terms of worship or religious knowledge like scholars. That way, Indonesian religious Muslims will give their trust. If this happens, it is not impossible that people's acceptance of their presence can make it easier for scholars to express their aspirations or even slowly be able to change the way people see the modern era.

If the two conditions above do not occur, in fact Muslim scholars and scholars can still work hand in hand in fulfilling their social duties. This is another option that may be desired by Muslim thinkers, namely cooperation between religious experts and science experts. The way to do this is by frequently engaging in interactive dialogues for the achievement of advanced community development. This dialogue is considered necessary to bring together two perspectives to avoid misunderstanding between them. That way, both scholars and scholars will complement each other's shortcomings.

Based on this explanation, the author agrees Dawam's statement that the concept of Muslim scholars who combine the power of dhikr-fikr is a typical product of Indonesia. Why? Because the above problems can only occur in this country or other places that have a similar context. The concept of Muslim scholars is very unlikely to emerge in secular countries that separate religious and non-religious affairs or in countries where Muslims are a minority.

However, the author also realizes that in any case the concept of ulil albâb in the Qur'an is not any product. It is very unethical to claim this concept specifically in Indonesia. The Qur'an first gave rise to the concept of ulil albâb in the 7th century long before the discovery of the concept of Muslim scholars who emerged only fourteen centuries later. Therefore, the authors consider the concept of Muslim scholars merely a product of the efforts of Indonesian Muslim thinkers in interpreting and practicing the contents of the Qur'an. This interpretation and practice may change if it is done by Muslims who live in different places or times.

Related to rebuilding Islamic civilization through literacy, the concept of ulil albâb is very applicable. With some of the characteristics that the author has described above, it can be seen how ulil albâb masters a lot of literacy. Ulil albâb reading al-Qur'an shows it has literacy reading. Ulil albâb reading and observing the universe means that he can master technology. Ulil albâb cares for and cares for humans and other creatures of God means he has social sensitivity. Finally, ulil albâb also always thinks and revisits what he already knows, this shows that they have a critical attitude. Based on these several things, contextualizing the concept of ulil albab is important, especially for Indonesian civilization. 
In the end, based on the description so far, we can learn that human understanding of the Qur'an can continue to change according to the context of life. The lengthy description of the writer also proves one of the miracles of the Koran, that as a guide to life he is timeless, he is likull zamân wa makân. And lastly, as a final note, the Qur'an as Zikr will not mean anything without reason to think about it. That's where the role of reason, making dhikr into thinking so thinking becomes dhikr. Allah.

\section{Conclusion}

Based on this qualitative research, the researcher found two main problems. The two problems are the dichotomy of the practice of religion and the imbalance in the practice of science. These two problems are interrelated. The dichotomy of religious practice is a general view which considers all activities other than Shari'a practices are not considered worship and are of no reward. This raises a second problem, namely the practice of religious knowledge is more dominant than general science. These are two factors that make Muslim literacy low. The concept of ulil albâb which combines the power of dhikr, thought and deed needs to be reactualized to overcome the problem.

\section{Acknowledgements}

The author thanks Mr. Kusmana, Ph.D and Dr. JM. Muslims who supported the author to write this research. Thank you also to the Indonesian Ministry of Religion for funding the author's participation in writing this work.

\section{References}

[1] OECD, PISA 2015 Assesment and Analytical Framework: Science, Reading, Mathematic and Financial Literacy, Paris: OECD Publishing, 2016.

[2] A. Asyhari, "Literasi Sains Berbasis Nilai-nilai Islam dan Budaya Indonesia," Jurnal Ilmiah Pendidikan Fisika Al-BiRuNi, pp. 137-148, 2017.

[3] F. J. Miharja, „Literasi Islam \& Literasi Sains Sebagai Penjamin Mutu Kualitas Manusia Indonesia di Era Globalisasi,“" Malang, 2016.

[4] K. Zada, Fathudin, D. Khairani, and Y. Durachman, "Reduce Extremism through Digital Literacy," 2020.

[5] B. Yatim, Sejarah Peradaban Islam Dirasah Islamiyah II, Jakarta: PT Rajagrafindo Persada, 2014.

[6] Oxford, Oxford Wordpower, New York: Oxford University Press, 2003.

[7] UNESCO, Education for All Global Monitoring Reportn2006, pp. 147-159.

[8] L. J. Moleong, Metodologi Penelitian Kualitatif, Bandung: PT. Remaja Rosdakarya, 2016.

[9] J. S. Suriasumantri, Filsafat Ilmu: Sebuah Pengantar Populer, Jakarta: Pustaka Sinar Harapan, 1996.

[10] M. D. Rahardjo, Ensiklopedi Al-Qur'an: Tafsir Sosial Berdasarkan Konsep-konsep Kunci, Jakarta: Paramadina, 1996.

[11] S. Susanti, „Kajian Kritis terhadap Konsepsi "Ulil Albab" dalam al-Qur'an“.

[12] J. Rahmat, Islam Alternatif, Bandung: Mizan, 1993.

[13] M. a.-L. al-'Arabiyah, Mu'jam al-Wasith, Jeddah: Maktabah Kunuz al-Ma'rifah, 2011.

[14] A. a.-H. A. i. F. i. Z. al-Razi, Maqayis fi al-Lughghah, Beirut: Dar al-Fikr, 1994. 
[15] M. Q. Shihab, Tafsir al-Misbah Pesan, Kesan dan Keserasian Al-Qur'an, Ciputat: Lentera Hati, 2000 .

[16] M. D. Rahardjo, Intelektual, Intelegensia dan Perilaku Politik Bangsa, Bandung: Mizan, 1999.

[17] A. H. a.-H. i. '. i. S. i. S. i. Y. i. M. al-'Askarî, Mu'jam al-Furûq al-Lughghawiyyah, Qum: Muassisah al-Nasyr al-Islâmî al-Tâbi’ah li Jamâ'ah al-Mudarrisîn, 1412 H.

[18] H. '. K., al-Mu'jam al-Mufassir li Alfâzi al-Qur'ân al-Karîm, Dâr al-I’tisâm, 1986.

[19] J. a.-H. Mahfûzah, al-Munjid fî al-Lughghah, Beirut: Dâr al-Masyriq, 1977.

[20] a.-T. Muhammad bin Jarîr bin Yazîd bin Katsîr bin Ghâlib al-Âmalî Abu Ja'far, Jâmi' al-Bayân fî̀ Ta'wîl al-Qur'ân, Muassasah al-Risâlah, 2000.

[21] A. '. M. b. A. b. A. B. b. F. a.-A. a.-K. S. a.-D. al-Qurtubî, al-Jâmi' li Ahkâm al-Qur'ân, Cairo: Dâr al-Kutub al-Misriyyah, 1964.

[22] A. a.-F. I. b. ‘. b. K. a.-Q. al-Dimasyqî, Tafsîr al-Qur’ân al-‘Adzîm, Dâr Tayyibah li al-Nasyr wa al-Tauzî’, 1999.

[23] M. a.-T. b. M. b. M. a.-T. b. ' al-Tûnisî, Muhammad al-Tâhir bin Muhammad binal-Tahrîr wa al-Tanwîr, Tunisia: al-Dâr al-Tûnisiyyah li al-Nasyr, 1984.

[24] B. Mudhary, Menjelajah Angkasa Luar (Analisa Metafisika al-Mi'raj), Surabaya: Pustaka Progressif, 1989.

[25] D. P. Nasional, Kamus Besar Bahasa Indonesia Pusat Bahasa, Jakarta: PT. Gramedia Pustaka Utama, 2008.

[26] M. D. A. B. Pius Partanto, Kamus Ilmiah Populer, Surabaya: Arkola.

[27] D. P. Nasional, Tesaurus Alfabetis Bahasa Indonesia Pusat Bahasa, Bandung: Mizan, 2009.

[28] F. G. French, Oxford Wordpower, Oxford University Press, 1999.

[29] Shahabuddin, Ensiklopedia Al-Qur'an: Kajian Kosa Kata. 